\title{
The Macroeconomic Consequences of Remittances
}

\author{
Dennis W. Jansen, ${ }^{1}$ Diego E. Vacaflores, ${ }^{2}$ and George S. Naufal ${ }^{3,4}$ \\ ${ }^{1}$ Department of Economics, Texas A\&M University, College Station, TX 77843, USA \\ ${ }^{2}$ Department of Finance and Economics, Texas State University-San Marcos, San Marcos, TX 78666, USA \\ ${ }^{3}$ Department of Economics, American University of Sharjah, Sharjah, UAE \\ ${ }^{4}$ IZA, 53113 Bonn, Germany
}

Correspondence should be addressed to Dennis W. Jansen, dennisjansen@tamu.edu

Received 30 May 2012; Accepted 22 July 2012

Academic Editors: J. M. Labeaga, U. Pascual, and M. Tsionas

Copyright (C) 2012 Dennis W. Jansen et al. This is an open access article distributed under the Creative Commons Attribution License, which permits unrestricted use, distribution, and reproduction in any medium, provided the original work is properly cited.

\begin{abstract}
This study examines the impact of a remittances shock on the main macroeconomic aggregates of a small open economy. It uses a stochastic limited participation model to generate dynamics that are consistent with the empirical literature, like the increase in inflation, consumption, and leisure. However, the remittances shock generates a prolonged decline in GDP, which only diminishes when remittances are a larger percentage of GDP, the fraction of remittances directed towards investment increases, or when the fraction of labor income that remittances represent is reduced and is overturned when the persistence of the remittances shocks is shortened.
\end{abstract}

\section{Introduction}

Remittances have been on the rise for the last several decades. International estimates of official remittance flows suggest that the total amount of remittances received by developing countries has surpassed 300 billion US dollars in 2011, from which almost 61 billion went to Latin America and the Caribbean (Inter-American Development Bank [1]). Their importance does not only come from their size, but also from their relative importance as a share of GDP in some countries and from their increasing share in all financial flows entering developing countries. They now represent approximately 45 percent of net capital inflows in these countries. The significant increase in remittances is attributed to the rapid growth of money transfer institutions, to the decreases in the average transaction cost of remitting, and also to a renewed surge in migration flows before the financial crisis.

Most of the existing literature on remittances concentrates on the microeconomic implication of such flows, for the sender or the receiver of these funds. Based on survey data, this strand of the literature has examined the motivation to remit-contractual arrangements, altruism, repayment of migration costs, and so forth-and the uses of these funds in the home country-for education, health care, entrepreneurial initiatives, social works, and so forth. However, despite the limitations in terms of data quality at the aggregate level, the increasing importance of remittances has led many researchers and policymakers to turn their attention to the potential impact that these financial flows can have on macroeconomic aggregates.

While recent research has shed some light on their potential influence on consumption and inflation (Narayan et al. [2] and Vacaflores [3]), on the exchange rate and trade competitiveness (Amuedo-Dorantes and Pozo [4] and Acosta et al. [5]), on labor supply (Funkhouser [6], Hanson [7], Chami et al. [8], Acosta et al. [5] and Jansen and Vacaflores [9]), on economic growth (Cáceres and Saca [10] and Osili [11]), and on policy responses (Chami et al. [8], Mandelman [12] and Vacaflores [3]), little attention has been placed on the potentially different effect that remittances shocks can have on the main macroeconomic aggregates depending on the distribution of remittances between consumption and investment, on the relative importance of remittances as a share of GDP, and on its relative importance in terms of income.

The correct understanding of the influence of remittances on macroeconomic aggregates under alternative specifications is crucial for policymakers to appropriately respond 
to these inflows. This paper incorporates remittances in a small open economy and uses a limited participation model to examine the dynamic response of the main macroeconomic aggregates to a positive remittances shock. The results show that a remittances shock increases consumption, inflation, and leisure, which produces a small initial decline in output. However, even if the remittances shock also generates a small decline in the interest rate, the persistent decline in labor reduces the marginal product of capital that leads to a temporary decline in investment. These two effects give way to a slow recovery of output, producing a prolonged contraction of GDP. The remittances shock reduces GDP in the short term but improves the utility of the representative household, with their specific effect on output being dependent on the uses (consumption or investment) and relative importance of remittances.

The paper is organized as follows. Section 2 presents a brief summary of the literature review. Section 3 formulates the theoretical model, and Section 4 discusses the results emanating from a remittances shock. Section 5 provides a robustness check, where the influence of the motive to remit and the relative importance of remittances are examined. Section 6 summarizes and concludes.

\section{Literature Review}

Residents of labor exporting countries receive substantial annual flows of remittances. Countries like the Philippines and Mexico received documented remittances of more than 22 billion US dollars in 2011 (Inter-American Development Bank [1]). IADB figures for 2011 show that remittances were almost 5\% of GDP in Ecuador, above 10\% in Guatemala, over 16\% in El Salvador, and approaching 18\% in Honduras. Even in larger economies such as Mexico their importance has reached levels close to $2 \%$ of GDP.

While there is a growing consensus on a number of effects that changes in remittances would generate (alleviation of consumption needs, increases in education and health care, the outflow of human capital, the additional pressure on the domestic currency, etc.), there are still others that are currently unsettled. Empirical evidence contributes to our understanding of these effects, such as in the case of inflation. Since remittance inflows generate additional economic activity-as they usually increase domestic consumptionthey are thought to generate inflationary pressures. Narayan et al. [2] confirm this effect in a set of 54 developing countries for the period 1995-2004, showing that remittances generate inflationary pressures, which becomes accentuated in the long run. Vacaflores [3] uses quarterly data and also finds that increases in remittances led to increases in inflation for a set of 11 Latin American countries in the last 15 years. The finding in Vacaflores et al. [13] showing that remittances contribute to the accumulation of international reserves in Latin America also suggests a positive impact on inflation. Specifically, to the extent that Central Banks feel the need to inject money into the economy to redeem these foreign currency remittances, they will increase the money supply unless they fully sterilize such flows.
The following effects are less conclusive, and consequently still contentious Starting with Lucas and Stark [14], there has been a push to discern the true impact on the economy depending on migrant's motivation to remit, be it altruism or self-interest. If the motive is altruistic, then economic downturns in the country of origin will prompt migrant workers to send more remittances in order to avoid consumption fluctuations for their families back home. If, on the other hand, migrant workers are self-interested, remittances will respond positively to improved economic conditions in the country of origin, as to take advantage of business opportunities. Some studies have found evidence of altruistic remittances (Chami et al. [15] and Frankel [16]), others of self-interest remittances (Barajas et al. [17] and Neagu and Schiff [18]), some studies that it depends on the country being examined (Durdu and Sayan [19]).

There is a growing consensus indicating that greater proportions of self-interested remittances-geared towards investment instead of consumption-are more effective in generating economic growth, giving way to an inherent push to direct more remittances towards investment initiatives. Some studies have shown that remittances are mainly used for consumption (Durand et al. [20]), generating an increase in demand, but others have shown that remittances can increase small business investment (Woodruff and Zenteno [21]) and human capital investment (Cox-Edwards and Ureta [22]), investment that can generate a larger impact on economic growth through a multiplier effect.

Irrespective of their use, higher levels of remittances should stimulate the demand for goods and services in the receiving country, providing an upward pressure on production. However, since recipient households should respond to the increased inflow of funds-increased income-by "purchasing" more leisure as well as more consumption, the initial contribution to output could well be ameliorated or overturned. While a variety of studies have shown that remittances have a negative effect on the work effort of the receiving household (i.e., Funkhouser [6], Chami et al. [8], Acosta et al. [5], and Hanson [7]) this result is being challenged. Jansen and Vacaflores [9] indicate that if one considers that remittances are not just a gift from relatives but is in fact a household decision regarding labor allocation, then these inflows may not have as a large bearing on the household's domestic work effort and, consequently, on domestic production. Some evidence of this more limited effect is found by Cox-Edwards and Rodríguez-Oreggia [23], for Mexico, and Funkhouser [24], for Nicaragua.

In terms of policy response, Chami et al. [8] show, in a stochastic dynamic general equilibrium model, that the optimal monetary policy follows the Friedman rule in economies with no remittances, while in remittancesdependent economies the optimal monetary response deviates from this rule, with governments having to resort to the use of the inflation tax. Vacaflores [3] unveils a differential impact from remittances shocks in economies with different degrees of sterilization, showing that partial sterilization gives rise to a more pronounced drop in the interest rate, and that the labor-leisure tradeoff is exacerbated due to indirect effects on the money growth and inflation. Similar in spirit 
but with an opposite outcome, the study of Mandelman [12] finds that a positive remittances shock generates inflation that is controlled by the monetary authority through a contraction of the money supply - a rise in the interest rate. This last study includes a monetary policy rule a la Taylormore representative of developed countries-that triggers an automatic response to inflation.

In the rest of this paper we develop and analyze a theoretical model in which remittances transfer resources from the rest of the world to households in a small open economy. A key feature of the model is the introduction of a financial intermediary that exists to redirect remittances to firms, where applicable, in order to draw a distinction between the effects of remittances through consumption versus investment. Households react as optimizing agents, increasing consumption and leisure in the steady state. We model remittances as occurring in foreign currency although the exact form of remittances is not crucial since goods are readily convertible into currency, local or foreign, and vice versa. This skirts issues related to the transfer problem discussed in the trade literature, which we do not address. Samuelson [25] provided a classic analysis of the transfer problem, showing that in a perfectly competitive two-country two-good world, the donor always has reduced welfare and the recipient increased welfare. The donor country's terms of trade may deteriorate if and only if the donor country's marginal propensity to consume its own exports is lower than the recipient country's marginal propensity to consumer the donor country's exports. Our small open economy focus allows us to rationalize our (implicit) assumption that remittances do not impact the remitting economy. Our model generates the expected effects of remittances on optimizing agents.

It is worth noting that our analysis has some similarities to the inflows of other types of resources (like official foreign aid), but our specification captures characteristics that are particular to remittances. Remittances enter the economy through the representative household (not a government) and are distributed proportionally (that is, they are not necessarily aimed at the poorest portion of the population). While remittances are specified to be primarily used for consumption, we allow a fraction to be used for investment. Of course, remittances do not respond to political considerations and are not subject to conditions on the use of such funds.

\section{Theoretical Model}

We adopt a limited participation model that requires money balances to be held to finance certain types of purchases, with households deciding in the distribution of these money balances - between money cash and money deposits - in the previous period. This model has been used to rationalize a large and persistent liquidity effect. To make this liquidity effect persistent we introduce an adjustment cost on cash money holdings, $M_{t}^{c}$.

We model the cost of changing money holdings similarly to Hairault et al. [26], who take into account the time spent on reorganizing the flow of funds. The adjustment cost is a time cost - a reduction in leisure in order to spend time adjusting money balances. The adjustment cost equation is as follows:

$$
\Omega_{t}=\frac{\xi}{2}\left(\frac{M_{t+1}^{c}}{M_{t}^{c}}-\theta\right)^{2} .
$$

The long-run value of $M_{t+1}^{c} / M_{t}^{c}$ is equal to the growth rate of money, represented by the parameter $\theta$, so both the level of $\Omega_{t}$ and its derivative with respect to $M_{t+1}^{c} / M_{t}^{c}$ are zero in the steady state. The cost of changing $M_{t}^{c}$ is an increasing function of the parameter $\xi$, and this parameter allows us to calibrate the size and persistence of the liquidity effect.

The cost of adjusting money holdings implies that bank deposits would not change significantly following a monetary shock, and consequently the additional funds will create a stronger and more persistent decline in the interest rate. In a flexible exchange rate regime this fall in the domestic interest rate will create an interest rate differential that will give rise to an overshooting of the exchange rate, a feature in accord with the stylized facts.

3.1. Structure of the Model. The goods market is characterized by perfect competition, with domestic firms, and the rest of the world producing an identical good whose price in domestic currency is given by $P_{t}$. The law of one price holds. Letting $s_{t}$ denote the price of foreign currency in terms of domestic currency, and keeping in mind that the small open economy assumption implies that the price of the good in foreign currency $\left(P^{*}\right)$ is exogenous, purchasing power parity is given by

$$
P_{t}=s_{t} P^{*}
$$

Thus in this economy the domestic price level changes one for one with the exchange rate.

3.1.1. The Household. The representative agent's objective is to choose a path for consumption and asset holdings to maximize

$$
\sum_{t=0}^{\infty} \beta^{t} U\left(C_{t}, L_{t}\right)
$$

where $C$ is real consumption and $L$ is leisure hours. We normalize the time endowment to unity, so leisure is given by $L_{t}=1-H_{t}-\Omega_{t}$, where $H$ is worked hours, and $\Omega$ is time spent adjusting money balances.

We specify a parametric constant elasticity of substitution (CES) per period utility function to facilitate calibration of our model as follows:

$$
U\left(C_{t}, L_{t}\right)=\frac{\left[C_{t}^{1-\gamma} L_{t}^{\gamma}\right]^{1-\sigma}}{1-\sigma} .
$$

Here $\gamma$ is the relative weight of leisure in the above utility function, and $\sigma$ defines the inverse of the intertemporal elasticity of substitution with $\sigma>0$ and $0<\gamma<1$. 

form:

The cash-in-advance (CIA) constraint takes the following

$$
P_{t} C_{t} \leq M_{t}^{c}+\phi s_{t} \Re_{t},
$$

where $M_{t}^{c}$ denotes cash brought forward from period $t-$ 1. With $\mathfrak{R}_{t}$ being remittances in foreign currency (i.e., dollars) and $s_{t}$ being the nominal exchange rate (i.e., pesos per dollar), then $s_{t} \mathfrak{R}_{t}$ are nominal remittances in domestic currency terms received by the household. The parameter $\phi$ takes values between 0 and 1 and indicates the percentage of remittances immediately available for consumption (as opposed to being held as bank deposits and only available for consumption in future periods) We introduce $\phi$ to allow us to study policies that induce (force) agents to keep a certain amount of remittances as deposits (increasing funds available for investment). This parameter is exogenous, and we view it as outside the control of households, a constraint imposed by the method of remittances entering the economy. Given the choice households would choose $\phi=1$, in order to relax the CIA constraint. This parameter allows us to change the channel through which remittances enter the economy and study the impact of such changes.

Households can hold foreign assets that yield a riskfree exogenous nominal interest rate $i_{t}^{*}$. In each period the household buys foreign assets $B_{t+1}$ denominated in the foreign currency, so the nominal exchange rate becomes a key variable in the portfolio decision.

The household budget constraint is given by

$$
\begin{aligned}
M_{t+1}^{c}+ & M_{t+1}^{b}+s_{t} B_{t+1}+P_{t} C_{t} \\
& \leq M_{t}^{c}+\phi s_{t} \mathfrak{R}_{t}+P_{t} w_{t} H_{t} \\
& +\left(1+i_{t}\right) M_{t}^{b}+s_{t}\left(1+i_{t}^{*}\right) B_{t}+D_{t}^{f}+D_{t}^{b} .
\end{aligned}
$$

At time $t$ the household determines consumption $C_{t}$ and labor supply $H_{t}$, as well as the amount of money deposited in banks, $M_{t+1}^{b}$, the amount of money kept as cash, $M_{t+1}^{c}$, and the foreign asset position $B_{t+1}$. Household income is determined by the real wage $w_{t}$ and the profits (or dividends) received at the end of the period from both the firm and the bank, $D_{t}^{f}$ and $D_{t}^{b}$, as well as interest on deposits and on foreign bonds.

The household's maximization problem can be represented by the value function as follows:

$$
\begin{aligned}
V\left(M_{t}^{c}, M_{t}^{b}, B_{t}\right) & \\
=\operatorname{Max}_{\left\{C_{t}, H_{t}, M_{t+1}^{c}, M_{t+1}^{b}, B_{t+1}\right\}}\{ & U\left(C_{t}, 1-H_{t}-\Omega_{t}\right) \\
& \left.+\beta E_{t} V\left(M_{t+1}^{c}, M_{t+1}^{b}, \frac{\xi}{45} B_{t+1}\right)\right\}
\end{aligned}
$$

subject to the cash-in-advance constraint (5) and the budget constraint (6). Letting $\lambda_{t}$ denote the Lagrangian multiplier associated with the budget constraint, the first-order conditions for the household's choice of consumption, labor, money deposits, money-cash holdings, and foreign assets provide the following relationships:

$$
\begin{gathered}
\lambda_{t}=\beta E_{t}\left[\left(1+i_{t+1}\right) \lambda_{t+1}\right] \\
-U_{H_{t}}^{\prime}=w_{t} P_{t} \lambda_{t} \\
s_{t} \lambda_{t}=\beta E_{t}\left[s_{t+1}\left(1+i^{*}\right) \lambda_{t+1}\right] \\
P_{t} w_{t} \lambda_{t} \frac{\xi}{M_{t}^{c}}\left(\frac{M_{t+1}^{c}}{M_{t}^{c}}-\theta\right)+\lambda_{t} \\
=\beta E_{t}\left[\frac{U_{C t+1}^{\prime}}{P_{t+1}}\right] \\
+\beta E_{t}\left[P_{t+1} w_{t+1} \lambda_{t+1} \frac{\xi M_{t+2}^{c}}{\left(M_{t+1}^{c}\right)^{2}}\left(\frac{M_{t+2}^{c}}{M_{t+1}^{c}}-\theta\right)\right] .
\end{gathered}
$$

Equation (8) requires equality between the costs and benefits of bank deposits, while (9) requires equality between the marginal disutility of working and the marginal benefitthe real wage multiplied by the Lagrange multiplier. Equation (10) requires equality of the current marginal cost of buying foreign assets (in terms of wealth) with the gains in the following period from holding such assets today, and (11) equates the costs and benefits related to the choice made at time $t$ of money holdings available for consumption in the following period. It is clear that if the adjustment cost is zero $(\xi=0)$, then (11) will just equate the household's cost of holding money in the current period to the marginal utility of consumption in the following period, properly discounted.

3.1.2. The Firm. We specify the firm's production technology using a Cobb-Douglas functional form:

$$
Y_{t}=e^{z_{t}} K_{t}^{\alpha} H_{t}^{1-\alpha} .
$$

Here $\alpha \in[0,1]$ and $K$ is physical capital. The firm's objective is to maximize the discounted stream of dividend payments, where we consider the value of this discounted dividend stream to households. The firm receives its profits at the end of the period, so the firm borrows funds from the bank to invest in physical capital at the beginning of the period, with the cost of borrowing given by the nominal interest rate $i_{t}$. Consequently, the nominal profits of the firm are given by

$$
D_{t}^{f}=P_{t} Y_{t}-P_{t} w_{t} H_{t}-P_{t}\left(1+i_{t}\right) I_{t}-P_{t} \Theta_{t}
$$

with investment evolving according to the law of motion of the stock of physical capital as follows:

$$
I_{t}=K_{t+1}-(1-\delta) K_{t}
$$

where $\delta$ is the (constant) depreciation rate. The parameter $\Theta$ in (13) is the adjustment cost of capital and is given by $\Theta_{t}=(v / 2)\left(K_{t+1}-K_{t}\right)^{2}$.

The decision about the use of dividends, either payments to households or reinvestment in the firm, is captured by the 
ratio of the multipliers associated with the budget constraint of the household in the value function (see (8)), as it reflects the consumer's variation in wealth. The value function of the firm is then as follws:

$$
V\left(K_{t}\right)=\operatorname{Max}_{\left\{H_{t}, K_{t+1}\right\}}\left\{D_{t}^{f}+E_{t}\left[\beta \frac{\lambda_{t+1}}{\lambda_{t}}\right] V\left(K_{t+1}\right)\right\}
$$

Note that the discount factor $\beta\left(\lambda_{t+1} / \lambda_{t}\right)$ can be written as $\left[E_{t}\left(1+i_{t+1}\right)\right]^{-1}$, reflecting the fact that the appropriate discount rate is time varying and reflects the expected value of the market-determined interest rate.

The first-order necessary conditions for the household's choice of labor and capital take the following forms:

$$
\begin{gathered}
w_{t}=(1-\alpha) \frac{Y_{t}}{H_{t}} \\
\left(1+i_{t}\right)+v\left(K_{t+1}-K_{t}\right) \\
=\beta E_{t}\left[\frac { P _ { t + 1 } \lambda _ { t + 1 } } { P _ { t } \lambda _ { t } } \left(\alpha \frac{Y_{t+1}}{K_{t+1}}+(1-\delta)\left(1+i_{t+1}\right)\right.\right. \\
\left.\left.+v\left(K_{t+2}-K_{t+1}\right)\right)\right] .
\end{gathered}
$$

Equation (16) indicates that the cost of hiring an additional worker should equal that worker's marginal productivity, and (17) requires equality between the cost and benefit of the marginal investment.

3.1.3. The Central Bank. The money stock evolves according to

$$
M_{t+1}=M_{t}+X_{t}
$$

where the Central Bank's money injection is defined as

$$
X_{t}=\left(\theta_{t}-1\right) M_{t},
$$

and $\theta_{t}$ represents the monetary growth factor. Equation (18) indicates that money growth in the economy depends on the existing stock of money $M_{t}$ and the monetary injection implemented by the central bank $X_{t}$.

The monetary growth factor $\theta_{t}$ is specified as an $\operatorname{AR}(1)$ process as follows:

$$
\log \left(\theta_{t+1}\right)=\left(1-\rho_{\theta}\right) \log (\bar{\theta})+\rho_{\theta} \log \left(\theta_{t}\right)+\varepsilon_{\theta, t+1} .
$$

We also must specify the processes governing the technology shock and the remittances shock in a similar fashion as follows:

$$
\begin{gathered}
\log \left(z_{t+1}\right)=\left(1-\rho_{z}\right) \log (\bar{z})+\rho_{z} \log \left(z_{t}\right)+\varepsilon_{z, t+1} \\
\log \left(g_{t+1}\right)=\left(1-\rho_{g}\right) \log (\bar{g})+\rho_{g} \log \left(g_{t}\right)+\varepsilon_{g, t+1} .
\end{gathered}
$$

Here $\varepsilon_{g, t+1}, \varepsilon_{\theta, t+1}$, and $\varepsilon_{z, t+1}$ are independent white noise innovations with variance $\sigma_{g}^{2}, \sigma_{\theta}^{2}$, and $\sigma_{z}^{2}$, respectively.
3.1.4. The Financial Intermediary. At the beginning of the period, the financial intermediary or "bank" receives deposits from the household, $M_{t}^{b}$, receives a portion of remittances as deposits, $(1-\phi) s_{t} \mathfrak{R}_{t}$, and receives a potential monetary injection as deposits, $X_{t}$ The monetary injection $X_{t}$ is a helicopter drop on banks, which can be lent in the current period $t$, earning interest that is then distributed back to the households at the end of the period. These funds are then available for lending to the firm to pay for the firm's investment in physical capital.

To make this clearer, the bank's nominal asset balance is given by

$$
P_{t} I_{t}=M_{t}^{b}+(1-\phi) s_{t} \Re_{t}+X_{t}
$$

Here $P_{t} I_{t}$ are the loans made to firms and the right hand side lists sources of funds including deposits, a portion of remittances, and the monetary injection.

Bank profits per period are equal to the interest on loans minus interest paid on deposits and on remittances deposited in banks. Note that the monetary injection directly into banks is a subsidy to the bank in that there is no interest expense incurred by the bank on those funds. Note also that we have equality between the loan rate and the deposit rate. In absent monetary injections, the bank earns zero economic profits as follows:

$$
D_{t}^{b}=\left(1+i_{t}\right) P_{t} I_{t}-\left(1+i_{t}\right) M_{t}^{b}-\left(1+i_{t}\right)(1-\phi) s_{t} \mathfrak{R}_{t} .
$$

Putting both expressions together, profits of the intermediary depend only on the money injection provided by the monetary authority as follows:

$$
D_{t}^{b}=\left(1+i_{t}\right) X_{t}
$$

3.1.5. Closing the Model. Since we are modeling a small open economy with international assets freely traded, the noarbitrage condition leads to the uncovered interest rate parity condition (UIP) - by combining (8) and (10). Remittances are modeled to be partially exogenous to better identify the effect of these transfers from abroad on the recipient economy. In particular, we do not model any dependence of remittances on migration flows, but instead take the current state of migration as fixed. We do model remittances as dependent on domestic output and prices (Jansen and Vacaflores [9] incorporate endogeneity between remittances and migration flows). We assume that foreign-currencydenominated remittances are responsive to income deviations from the steady state in the recipient nation, and to inflationary pressures in the recipient nation. Thus remittances increase when the receiving country experiences an economic downturn, as in Chami et al. [8]. The remittances specification is given by as following:

$$
\mathfrak{R}_{t}=E_{t}\left[\vartheta P_{t}\left(\frac{Y^{s s}}{Y_{t}}\right)^{\tau} e^{g_{t}}\right] .
$$

A special case is $\tau=0$, so that remittances respond only to the domestic price level and to the shock $g$. For $\tau>0$, remittances react to the state of the recipient economy, rising 
when the state of the economy worsens (countercyclical). Also note that remittances increase when the domestic price level of the remittance-receiving country increases, which captures the idea that remitters are concerned with the purchasing power of the funds sent to the remittancereceiving country.

We follow Karamé et al. [27] and introduce an interest rate differential on bond holdings as

$$
i_{t}^{*}=i^{W}-\varphi \frac{s_{t-1} B_{t}}{P_{t-1}},
$$

where the interest in bonds is determined by the world interest rate and the net real foreign asset position, with $\varphi$ calibrating the asset position. This assumption leads to a lower bond rate as the country's net asset position improves. That is, the more foreign bonds held (valued in local currency), the lower is the interest rate on those bonds. This assumption helps avoid an instability problem with nonstationary behavior on bond holdings. (See Kollman [28] and Ghironi [29] for more on this issue).

3.2. Equilibrium. Note that the household would hold an amount of foreign assets that allows it to maximize its utility, subject to its budget constraint. From (6) and market equilibrium we can find the evolution of foreign asset holdings as follows:

$$
\begin{aligned}
s_{t} B_{t+1} & -s_{t}\left(1+i_{t}^{*}\right) B_{t} \\
& =P_{t}\left(Y_{t}-C_{t}-I_{t}-\frac{v}{2}\left(K_{t+1}-K_{t}\right)^{2}\right)+s_{t} \boldsymbol{R}_{t} .
\end{aligned}
$$

Equation (27) relates domestic production and absorption to an economy's foreign asset position, giving the balance of payments equilibrium. If a country's production is greater than its absorption, that country has a balance of trade surplus and a negative capital account, so its foreign asset holdings will increase when there are no remittances flowing into the country. Of course, the actual equilibrium impact of remittances on future bond holdings depends on its impact on output, consumption, and investment.

The set of equations given by the first-order conditions, the market equilibriums, and the laws of motion for physical capital, domestic money supply, foreign assets, and the monetary growth factor constitute a nonlinear dynamic stochastic system. The system's equilibrium is characterized by the set of prices and quantities arising from the household's maximization of its expected intertemporal utility, subject to the CIA and budget constraints, the firm's maximization of profits, and from the behavior of the labor market, the loanable funds market, and the money market, all clearing while satisfying purchasing power parity. To solve this system we calibrate basic parameters and find the steady-state values of the relevant variables to characterize the long-run equilibrium of the economy.

3.3. Calibration and Steady-State Equilibrium. Table 1 lists the values we assign to the basic parameters. The three first parameters follow standard calibration. The capital share, $\alpha$, is set to 0.4. The subjective discount factor $\beta$ is set at 0.988 , implying a real interest rate equal to $1.2 \%$ per quarter. The depreciation rate on capital is set to $2.5 \%$ per quarter. We initially set the time devoted to work to $25 \%$ of total time, approximately 42 hours per week, to solve for the parameter $\gamma$, but then fix $\gamma$ to solve for work hours. (Fixing $H$ to find $\gamma$ first is necessary given the more accurate measurement of $H$, but such procedure constrains labor to adjust to alternative levels of remittances, making the steady-state analysis limited. This procedure allows us to pinpoint the value of $\gamma$ and then allows labor to adjust to our alternative calibrations, creating richer dynamics in labor, output, and so forth).

The calibration of specific parameters is based in data, at quarterly frequency, from the 14 Latin American countries used in this study: Bolivia, Brazil, Colombia, Costa Rica, Dominican Republic, Ecuador, El Salvador, Guatemala, Honduras, Mexico, Nicaragua, Paraguay, Peru, and Uruguay. The data covers from 1995:1 to 2010:4 and was collected from individual Central Banks, for remittances, and the International Financial Statistics (IMF), for measures of money, output, CPI, consumption, and the trade balance. We emphasize that we are calibrating to averages from this set of countries, and not to any one nation.

The parameter $v$ represents the average of the trade balance as a percentage of GDP and is used to determine the long-run real debt-to-GDP ratio. The long-run gross inflation factor is given by $\Pi$ and is based on the average inflation rate of the countries in our sample. Remittances are calibrated to be 5 percent of GDP by setting the parameter $\vartheta$.

We use our panel data to estimate the persistence parameters using the Least Square Dummy Variable Correction (LSDVC) estimator. The persistence coefficient of the remittance's shock, $\rho_{g}$, and the standard deviation of the remittance's innovation, $\sigma_{g}$, are obtained from regressions on the level of remittances, while the persistence coefficient of the monetary shock, $\rho_{\theta}$, and the standard deviation of the monetary innovation, $\sigma_{\theta}$, are obtained from regressions on the monetary growth rate of the countries in the sample. We calibrate the technology shock, persistence, and variance, to standard levels.

We explicitly consider the case of a small but positive adjustment cost parameter, $\xi=3$, to allow for the liquidity effect-representing approximately 3.5 minutes per week of lost time rearranging money cash balances. The system of equations - and the log-linearized system-that describes the small open economy are available in the author's web page (http://www.business.txstate.edu/users/dv13/resea -rch.htm). Nominal variables are made stationary by dividing them by the lagged domestic price level. The main variables are:

$$
\begin{array}{lll}
m_{t}=\frac{M_{t}}{P_{t-1}} ; & m_{t}^{b}=\frac{M_{t}^{b}}{P_{t-1}} ; & \pi_{t}=\frac{P_{t}}{P_{t-1}} ; \\
b_{t}=\frac{s_{t-1} B_{t}}{P_{t-1}} ; & \Gamma_{t}=\frac{s_{t} \mathfrak{R}_{t}}{P_{t-1}} . &
\end{array}
$$


TABLE 1: Model calibration values.

\begin{tabular}{lccccc}
\hline$\alpha=0.4$ & $\beta=0.988$ & $\delta=0.025$ & $H=0.25$ & $\nu=-0.086$ & $v=0.08$ \\
$\vartheta=0.018$ & $s=3$ & $\theta=1.045$ & $\phi=0.9$ & $\rho_{\theta}=0.19$ & $\sigma_{\theta}=0.0465$ \\
$\tau=0.8$ & $\xi=3$ & $g=1.04$ & $\sigma=0.99$ & $\rho_{g}=0.96$ & $\sigma_{g}=0.14$ \\
$\varphi=0.009$ & & & $\rho_{z}=0.95$ & $\sigma_{z}=0.00816$ \\
\hline
\end{tabular}

3.3.1. Steady-State Equilibrium. It is assumed that the domestic gross inflation rate is given by the gross money growth rate $(\Pi=\theta)$ in the long-run equilibrium, and that adjustment costs disappear in the steady state. Given the parameter values of Table 1 , it is straight forward the derivation of steady-state values for the variables of the system of equation (available in the author's web page). Table 2 presents the steady-state values of a small open economy that uses 90 percent of remittances for consumption (and the remaining 10 percent for investment) under four alternative scenarios for the level of remittances as a percentage of GDP: 0 percent, 2 percent, 5 percent, and 10 percent of GDP.

As it can be observed, our small open economy has an inflation rate of 4.5 percent per quarter, which leads to a nominal interest rate of 5.77 percent per quarter. Investment in the economy without remittances is almost 25 percent of GDP while consumption is approximately 82 percent of GDP, with the trade deficit allowing for these higher levels (around 8.6 percent of GDP). Output is affected somewhat by the increase in remittances and falls by $1.5 \%$ when remittances rise from $0 \%$ to $2 \%$, by $3.5 \%$ as remittances rise from $0 \%$ to $5 \%$, and by $7.1 \%$ when remittances rise from $0 \%$ to $10 \%$. This occurs because the capital stock and labor hours are also reduced by similar percentages. Meanwhile consumption is higher by about $0.5 \%$ as remittances rise from $0 \%$ to $2 \%$, by $1.2 \%$ as remittances rise from $0 \%$ to $5 \%$, and by $2.5 \%$ when remittances rise from $0 \%$ to $10 \%$.

Thus a permanent increase in remittances results in households choosing more leisure and more consumption, and consequently increasing utility (see (4)). The per-period utility increase that occurs when remittances increase from $0 \%$ to $2 \%$ of GDP is equivalent to a ceteris-paribus increase in steadystate consumption of $1.5 \%$ (calculated at the steadystate consumption level when remittances are $0 \%$ of GDP). Alternatively, the per-period utility increase is equivalent to a ceteris paribus increase in leisure hours of $2.2 \%$. The increase in utility when remittances increase from $0 \%$ to $5 \%$ of GDP is equivalent to an $3.6 \%$ increase in consumption or a $5.3 \%$ increase in leisure hours, and the increase in utility when remittances rise from $0 \%$ to $10 \%$ of GDP is equivalent to a $7.5 \%$ increase in consumption or a $10.7 \%$ increase in leisure hours. Thus, remittances are good for households but do not necessarily lead to an increase in steady-state domestic production.

\section{Dynamics}

The baseline specification of the small open economy considers the case of small positive adjustment cost in the rearrangement of money balances of about 3.5 minutes per week $(\xi=3)$, allocates remittances to be used primarily towards consumption $(\phi=0.9)$, assumes an elasticity of substitution that preserves the wealth effect response to monetary shocks $(\sigma=0.99)$, and calibrates the economy to be representative of one in which remittances are $5 \%$ of GDP. The model generates dynamics from monetary and technology shocks that are in accord with the stylized facts. The monetary shock generates inflationary pressure, a prolonged drop in the interest rate that allows for an increase in investment, an initial drop in work effort from the wealth effect that produces an initial drop in output, and a subsequent reversal in work effort that combines with the higher capital to produce the typical hump-shape response in output. The technological shock alleviates inflation, increases the interest rate, and pushes the real wage up, causing an instantaneous increase in work effort that combines with higher levels of capital to result in a prolonged increase in output (The dynamics for these two shocks are available in the author's web page).

In order to examine the impact of a remittances shock on the main macroeconomic aggregates, we introduce a 1standard deviation shock (approximately a 14\% increase) to remittances. This is similar to the average growth rate of remittances flowing to Latin America during the 20002008 period $(15 \%)$. The main results are presented below in Figure 1 and show that a positive remittances shock that is primarily directed towards consumption will lead to an increase in the demand for the consumption good, exerting an upward pressure on inflation at the time of the shock. This is because remittances enter the CIA constraint and add to demand for goods and services. The remittances shock generates an increase in purchasing funds, which is big enough to outweigh the fall in real money cash balances caused by the higher inflation, and leads to an increase in consumption of more than $0.3 \%$. The high persistence of the remittances shock determines the subsequent dynamics of consumption, producing a slow monotonic decline in consumption.

This rise in remittances also generates an instantaneous slight reduction in the interest rate ( 4 basis points), as the percentage of remittances that are allocated for savings increase the amount of funds available for lending enough to outweigh the slight increase in inflation. The dynamics of the nominal interest rate after the period of the shock are governed by the dynamics of investment and money deposits. Starting in the second period, a reduction in the household's money deposits $\left(M_{t+1}^{b}\right)$ together with the temporarily above-steady-state investment generates an upward pressure on the interest rate that forces a monotonic increase. The remittances shock generates a liquidity effect, as shown in the top of Figure 1. 
TABLE 2: Steady-state values (gamma given).

\begin{tabular}{|c|c|c|c|c|}
\hline & Remittances & Remittances & Remittances & Remittances \\
\hline & $0 \%$ of GDP & $2 \%$ of GDP & $5 \%$ of GDP & $10 \%$ of GDP \\
\hline Inflation & 1.0450 & 1.0450 & 1.0450 & 1.0450 \\
\hline Nominal interest rate & 0.0577 & 0.0577 & 0.0577 & 0.0577 \\
\hline Nom. interest on bonds & 0.0577 & 0.0577 & 0.0577 & 0.0577 \\
\hline Capital/output ratio & 10.1810 & 10.1810 & 10.1810 & 10.1810 \\
\hline Investment & 0.3098 & 0.3052 & 0.2989 & 0.2878 \\
\hline Capital & 12.3922 & 12.2060 & 11.9542 & 11.5137 \\
\hline Hours worked & 0.2591 & 0.2552 & 0.25 & 0.2407 \\
\hline Output & 1.2172 & 1.1989 & 1.1742 & 1.1309 \\
\hline Real wages & 2.8185 & 2.8185 & 2.8185 & 2.8185 \\
\hline Consumption & 1.0121 & 1.0174 & 1.0246 & 1.0372 \\
\hline Remittances & 0 & 0.0240 & 0.0564 & 0.1132 \\
\hline Bonds & 8.6185 & 8.4890 & 8.3138 & 8.0075 \\
\hline Real money balances & 1.3219 & 1.2996 & 1.2694 & 1.2167 \\
\hline Real money cash & 1.0576 & 1.0416 & 1.0199 & 0.9820 \\
\hline Real money deposits & 0.2643 & 0.2580 & 0.2495 & 0.2347 \\
\hline$\Lambda$ & 0.3160 & 0.3143 & 0.3122 & 0.3084 \\
\hline Trade balance & -0.1047 & -0.1031 & -0.1010 & -0.0973 \\
\hline Utility & 99.8060 & 99.8112 & 99.8182 & 99.8304 \\
\hline
\end{tabular}
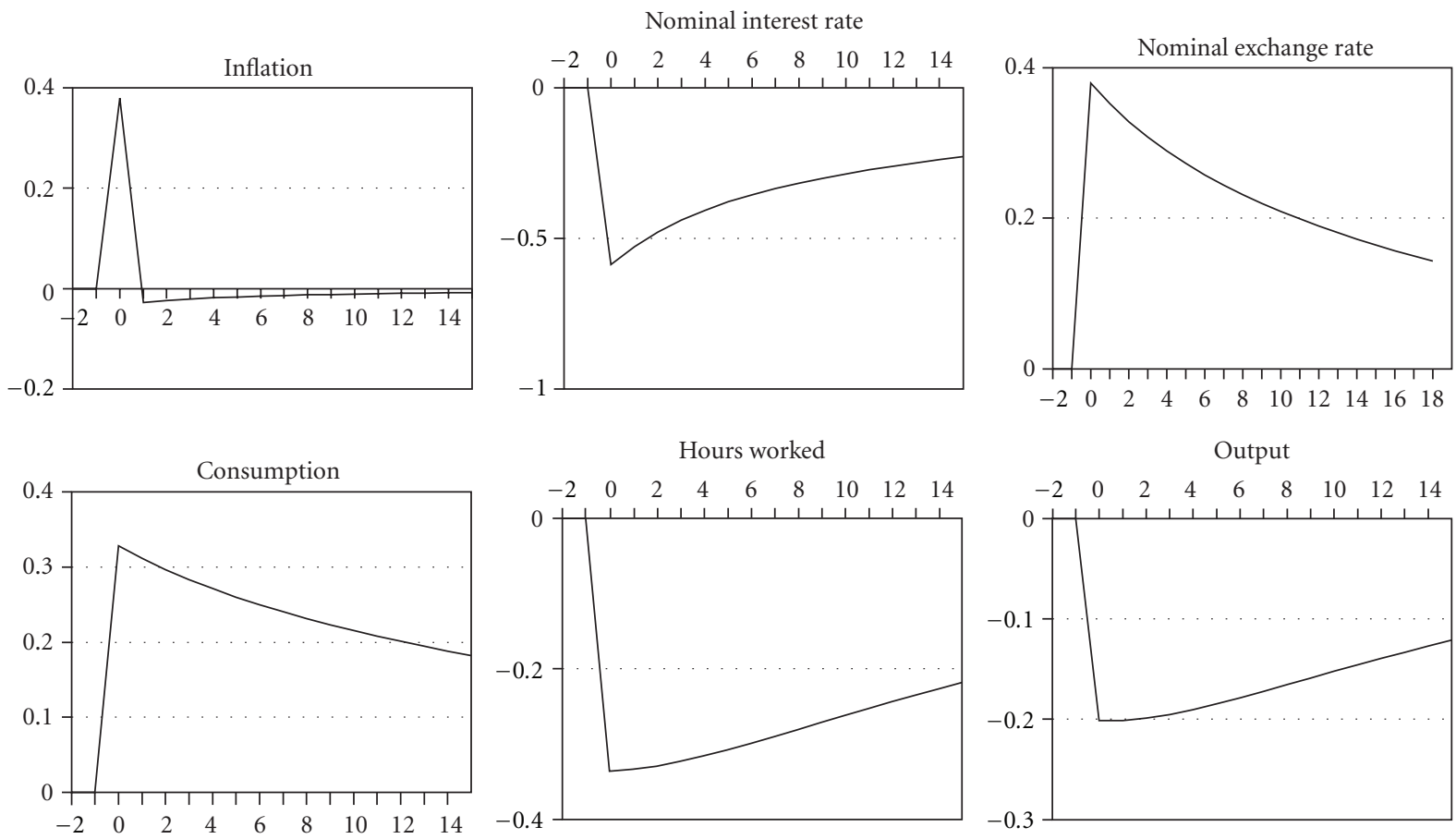

FIGURe 1: Dynamic response to a 1-standard deviation remittances shock. Percent deviation from steady state in vertical axis and quarters in horizontal axis.

The remittances shock also generates an overshooting of the exchange rate. The increase in consumption produces an upward pressure on inflation that is directly translated into an increase of the exchange rate (a depreciation). The subsequent appreciation of the exchange rate arises from the interest rate differential, which is required to be equal to the expected rate of appreciation of the following periods (uncovered interest rate parity condition). The remittances shock also induces agents to increase their holdings of foreign bonds, as the depreciation of the domestic currency and the drop in the domestic interest rate increase the return on foreign assets. 
The impact on output is dependent on the behavior of capital and labor. The remittances shock increases the purchasing power of the recipient, a wealth effect, that gives rise to a slight decline in labor. Since the capital stock is fixed for a period, this reduction in labor causes a small decline in output on impact. However, the high persistence of the remittances shock gives way to a prolonged contraction in labor that subsides slowly, even as the economy experiences above steady-state wages. The lower supply of labor also lowers the marginal product of capital, producing a small decline in capital before experiencing a prolonged accumulation. This lower work effort and availability of capital keeps output depressed for a couple of periods before starting to recover, as shown above in the bottom section of Figure 1. It is only when investment-and thus capital - and worked hours recover, that output increases monotonically.

These model dynamics are in accord with empirical evidence. An increase in remittances creates inflationary pressure in our model, as that found by Narayan et al. [2], Vacaflores [3], and Mandelman [12]. In terms of the interest rate response, Giuliano and Ruiz-Arranz [30] provide evidence of the beneficial effect that remittances have in alleviating liquidity constraints, and Aggarwal et al. [31] show that remittances have a positive impact on financial sector development. These findings are reflected in our model through the liquidity effect. In terms of the effect on the real exchange rate, the dynamics indicate a muted effect on impact (the percent deviations in inflation and the exchange rate are identical) but a real exchange rate appreciation thereafter, as suggested by Amuedo-Dorantes and Pozo [4], Cáceres and Saca [10], and Acosta et al. [5].

With regards to the effect on consumption, only microeconomic studies are able to measure the positive contribution to the consumption of the remittances-receiving households (Keely and Tran [32], León-Ledesma and Piracha [33], and De Haas [34]), with macroeconomic studies only suggesting that remittances increase consumption (Ratha [35], Cáceres and Saca [10], and Chami et al. [8]). Our paper strengthens this link by showing that remittances channeled for consumption do in fact increase consumption.

In terms of the impact on the recipient's work effort, our results support the finding that work effort declines due to an increase in remittances (i.e., Hanson [7]). However, our results for output, and investment, are more controversial. While most empirical studies find an initial decline in output (Cáceres and Saca [10] and Funkhouser [6]) followed by a temporary recovery (World Bank [36] and Barajas et al. [17]), our prolonged drop in output can be explained by the sustained decline in labor; an almost permanent increase in remittances generates a very persistent decline in work effort.

While the dynamics that arise from the remittances shock provide interesting insight on the channels through which remittances affect the macroeconomic aggregates, its overall impact on the welfare of the receiving household and on the trade balance are equally important. In terms of the utility of the representative household, the increase in consumption and leisure (the decrease in worked hours) is large enough to outweigh the adjustment cost on money balances (which reduces leisure), so that the welfare of the remittancesreceiving household experiences a temporary improvement. Of course, the larger the amount of remittances that are used for consumption instead of investment, the larger the beneficial effect. In terms of the impact on the adjusted trade balance (since we are including remittances to domestic production to then subtract domestic absorption), the results show that a remittances shock has a positive impact on the trade balance in the short run. While the remittances shock generates a slight drop in output, the increase in remittances is enough to compensate for this drop and outweighs the increase in consumption (and the small drop in investment). Now, if the current account omits remittances, we would have a deterioration of the trade balance, as the remittances shock has its largest effect on consumption, and given the slight decline in output this increase in consumption can only arise by higher imports from abroad.

\section{Robustness of the Remittances Shock}

Having established the adequacy of the model to unveil the dynamics emanating from a remittances shock, we now turn our attention to the analysis of specific assumption that can potentially have an impact on the behavior of the main macroeconomic aggregates. In particular, we examine how our results change with changes in the distribution of remittances between consumption and investment, in the relative importance of remittances as a share of GDP, in its relative importance in terms of income, and in the degree of persistence of the remittances shock. The benchmark calibration still has remittances being 5 percent of GDP.

We start our robustness check by increasing the proportion of remittances channeled towards the financial intermediaries (and thus reducing the proportion available for consumption) and examine the impact of a remittances shock as we allow for its effect to work its way through investment. It is reasonable to assume that remittances that are sent for altruistic reasons would tend to be spent on consumption and that remittances that are sent for selfinterest reasons would tend to be used for investment initiatives.

Our baseline calibration that channels 90 percent of the remittances towards consumption and allows 10 percent to be used for deposits (investment) is represented here by the dashed line. As we lower the amount of remittances available for consumption from $\phi=.95$ to $\phi=.90$ and then to $\phi=.85$, the initial spike in inflation is slightly higher, but as more funds are directed towards investment the fall in the nominal interest rate becomes accentuated and thus generates a slightly stronger liquidity effect, as shown below in the top center of Figure 2. This stronger liquidity effect provides greater incentives to increase investment, generating a smaller initial decline in capital. This additional inflation also leads to a higher initial depreciation of the nominal exchange rate. As expected, consumption's dynamic response becomes smaller as we reduce the percentage of remittances used to finance consumption, producing an improvement in consumption that is almost 25 percent smaller as we allow 
for the fraction available for consumption to fall from 95 to 85 percent.

In the bottom of Figure 2 we observe the dynamics of capital and labor, which determine the behavior of output. The remittances shock generates a wealth effect that lowers work effort on impact, with higher fractions of the remittances shock directed towards investment creating a smaller drop in work effort. The smaller drop in labor leads to a smaller fall in the marginal product of capital, which combines with the more pronounced liquidity effect to generate a prolonged accumulation in capital. Output falls by a smaller amount on impact, but the increase in the fraction of remittances devoted to investment produces a subsequent recovery of labor and capital that allows for a quicker recovery of output, as observed in the bottom-right dynamics of Figure 2.

We now turn to the differential impact that remittances can have on macroeconomic aggregates depending on their relative importance in the economy and on the income of the receiving household. We first analyze the same remittances shock on economies with increasing steady state levels of remittances as a percentage of GDP. This different "dependence" on remittances should have implications on the behavior of the remittances-receiving households and on the main macroeconomic aggregates. We present the case when remittances are $2 \%$ of GDP with a solid line, the baseline case when remittances are $5 \%$ of GDP with a dashed line, and the case when remittances are $10 \%$ of GDP with a dotted line.

It should be clear that a similar size remittances shock would result in a larger net shock on the receiving economy when the share of remittances as a percentage of GDP is larger. The one standard deviation (approximately 14\%) increase in remittances would result in a $0.28 \%$ shock in GDP terms in the case of remittances being $2 \%$ of GDP while the same one standard deviation would result in approximately $0.7 \%$ shock in GDP terms when remittances are 5\% of GDP. The one standard deviation remittances shock increases consumption and generates inflationary pressure, but since a higher relative importance of remittances imply that the same shock would provide greater overall income to the receiving household in an economy where remittances are a higher percentage of GDP, the relatively larger purchasing power would lead to a relative larger improvement in consumption. Of course, this would also lead to relatively higher inflation in this case. These relatively larger inflows also create a larger liquidity effect, since this depends on the relative addition of loanable funds. Relatively higher inflation and lower interest rate leads to a more pronounced overshooting of the exchange rate.

This same one standard deviation shock to remittances would also have a differential effect on the labor response, because now the increase in remittances has a larger impact on overall income as the share of remittances in GDP increases. The remittances shock will consequently generate a greater wealth effect as the relative importance of remittances increases, causing a more pronounced drop in work effort on impact that generates a larger initial drop in output. This larger drop in labor means that the marginal product of capital falls by more as we raise the percentage of remittances as a share of GDP, a decline large enough to outweigh the drop in the interest rate as to create a more pronounced initial decline in investment. However, this enhanced liquidity effect will lead to a much faster and stronger recovery in investment, and capital, which together with the subsequent recovery of labor will lead to a faster recovery of output (although remains below the steady state). The long-term effect of the same size remittances shock is an accentuated decline in output in economies where remittances are a larger share of GDP as shown in Figure 3.

To examine the potentially different response that the main macroeconomic aggregates can have from alternative levels of importance of remittances in the income of the representative household we allow the amount of worked hours $(H)$ to vary, thus affecting labor income generated by the representative household. We allow the parameter $\gamma$ - the relative weight of leisure in the utility function-to vary, and we examine the cases when the representative agent spends 20 percent of total time working (33.6 hours per week), the baseline 25 percent of total time working ( 42 hours per week), and 30 percent of total time working (50.4 hours per week). We retain the basic calibration of remittances being $5 \%$ of GDP, $90 \%$ of which goes towards consumption.

Figure 4 below presents the results of the positive onestandard deviation shock on remittances and indicates that the remittances shock produces a slightly smaller decline in the interest rate as we increase the steady-state allocation of time working, $H$. The increase in remittances creates a relatively smaller increase in loanable funds available for lending. Also, since the inflow of resources coming from remittances is a relatively smaller contribution to the income of the representative household as the steady-state amount of time devoted to work increases, the increase in remittances will create a relatively smaller increase in consumption, which consequently produces a slightly smaller increase in inflation. While not shown in the graph below, this relatively smaller inflationary pressure will lead to a smaller initial depreciation of the exchange rate, which combined with the smaller reduction in the domestic interest rate reduces the amount of foreign bonds being accumulated.

The output response to a remittances shock when we have a larger $H$ is determined by the relation between the predetermined capital and labor. The household earning more from the additional time spent working, which makes the inflow of remittances relatively less important, generates a smaller wealth effect that leads to an initial smaller drop in work effort. This leads to the smaller initial drop in output observed in the bottom-right corner of Figure 4. Furthermore, the relatively smaller decline in the marginal product of capital is large enough to compensate for the smaller liquidity effect to lead to a smaller decline in investment (and stronger subsequent recovery) as the steady state of $H$ is increased, which leads to a larger accumulation of capital. This combines with the recovery of work effort to produce a quicker recovery of output, reducing the overall negative effect on output from the remittances shock-as the steady-state working hours increases. 


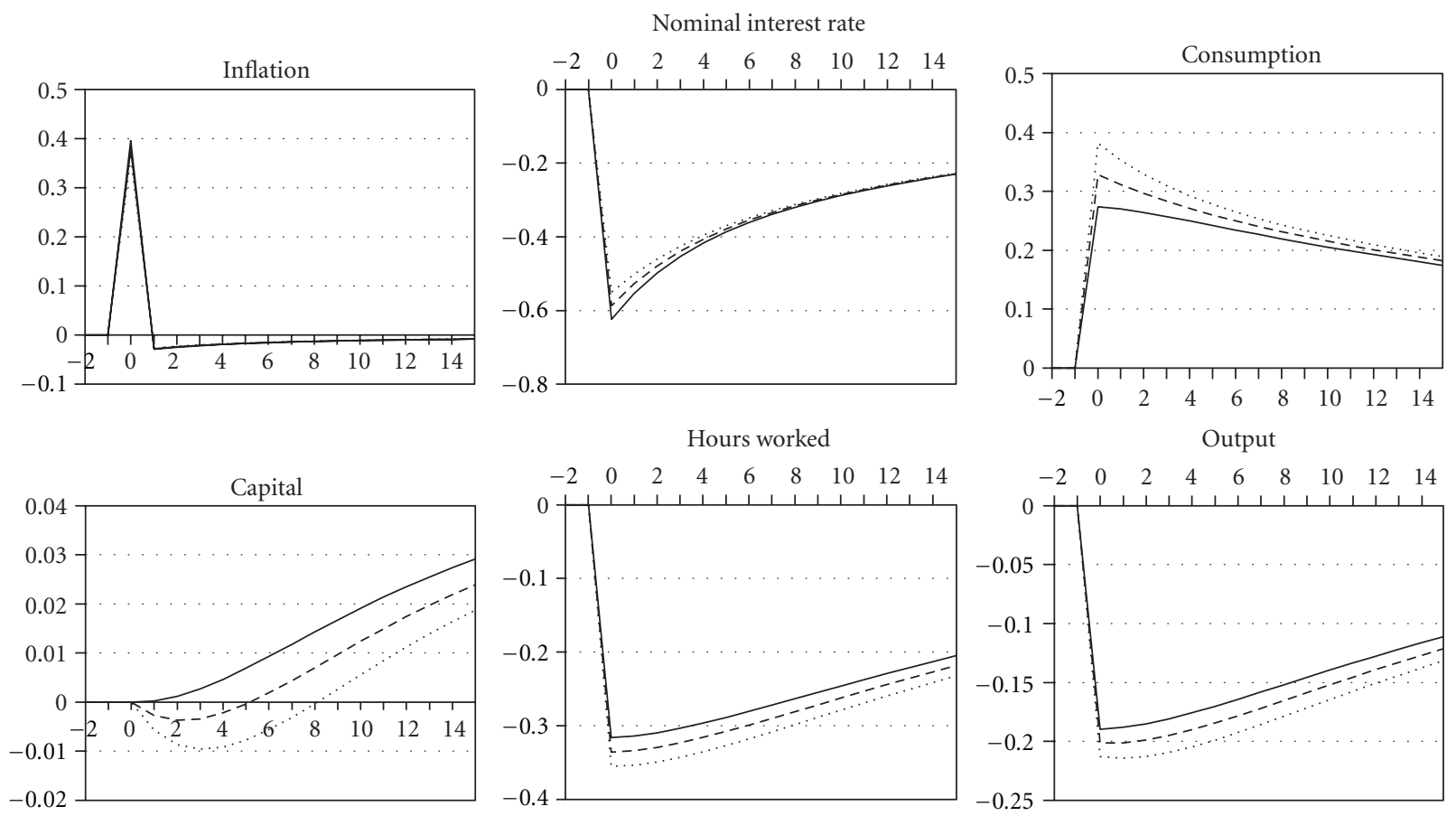

FIGURE 2: Dynamic response to a 1 standard deviation remittances shock. Percent deviation from steady state in vertical axis and quarters in horizontal axis. . . 5\%, - - - 10\%, — $15 \%$ of remittances for Investment.

We conclude this robustness check by examining the potentially different response that the main macroeconomic aggregates can have from alternative degrees of persistence that the remittances shock could actually have. The longterm data indicates a high degree of persistence (0.96), more nearly a permanent change, which could be arising from the continuous formalization of these capital flows. However, the double-digit drop in remittances experience in Latin America in 2009 as a result of the financial crisis was overturned by mid-2010 (IADB [1]), indication that our modeling of the persistence of the shock should perhaps be more conservative. We implement this here by adjusting the persistence parameter, presenting the case with the largest persistence with a solid line and the case with the smallest persistence with the dotted line.

The top-left panel of Figure 5 describes the dynamics of remittances. The decline in the persistence of the remittances shock leads to a smaller inflationary pressure in the receiving economy, as households expect the additional inflow of remittances to be short lived and thus reduce their work effort by a smaller fraction (same amount of remittances chase a relatively larger amount of goods). The smaller inflation emanating from the smaller degree of persistence has a twofold effect; it creates a larger initial increase in consumption and a smaller decline in the interest rate. The subsequent dynamics of consumption respond to the behavior of remittances, reverting faster to the initial level when the persistence of the shock is smaller. The subsequent response of the interest rate stems from the relatively smaller demand for loans, since the decline in labor is reduced as the persistence parameter is lowered, and the smaller increase in deposits available for lending, as the inflow of remittances dissipates more rapidly with the smaller degree of persistence. The exchange rate depreciates by less as the persistence parameter is lowered and returns to equilibrium more smoothly since the interest rate differential is reduced.

The dynamics governing output are presented in the bottom section of Figure 5. The lowering of the persistence parameter leads to a smaller decline in the interest rate, but it is large enough to outweigh the relatively smaller decline in the marginal product of capital from the reduced fall in labor, overturning the decline in investment and giving way to an accumulation of capital. Output drop on impact by a smaller percentage as the remittances shock is short lived. More interestingly, even if capital accumulation peaks sooner-and starts to decline thereafter-when the persistence parameter is lowered, the recovery of labor is much faster, returning to the steady-state level in 5 quarters when the persistence parameter is set to 0.5. The bottomright panel of Figure 5 shows that the negative effect of output is much smaller when the remittances shock is more transitory and in fact produces an increase in output to above steady-state levels sooner when the persistence parameter is reduced.

\section{Conclusions}

Our limited participation model with remittances is able to capture the qualitative behavior of the main macroeconomic aggregates in response to a remittances shock, in accord with empirical evidence. This study extends the literature by evaluating the macroeconomic dynamics that emanate 

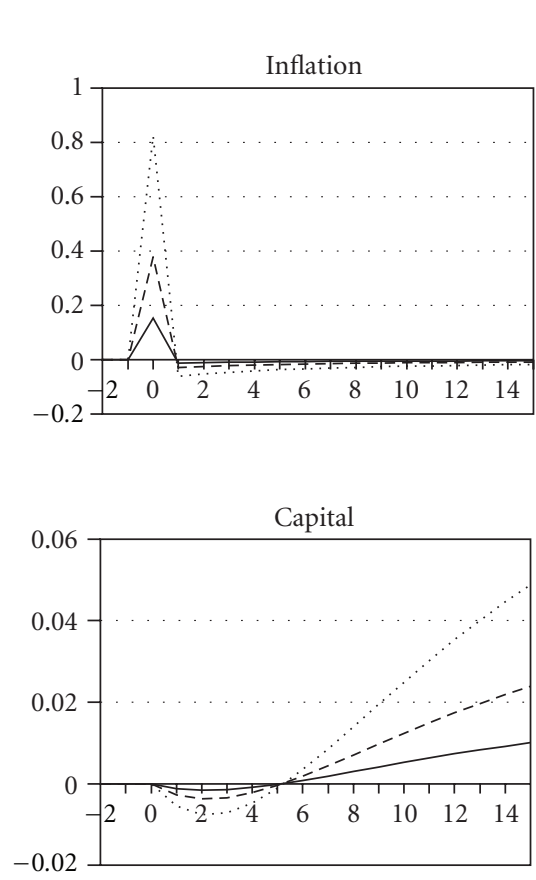
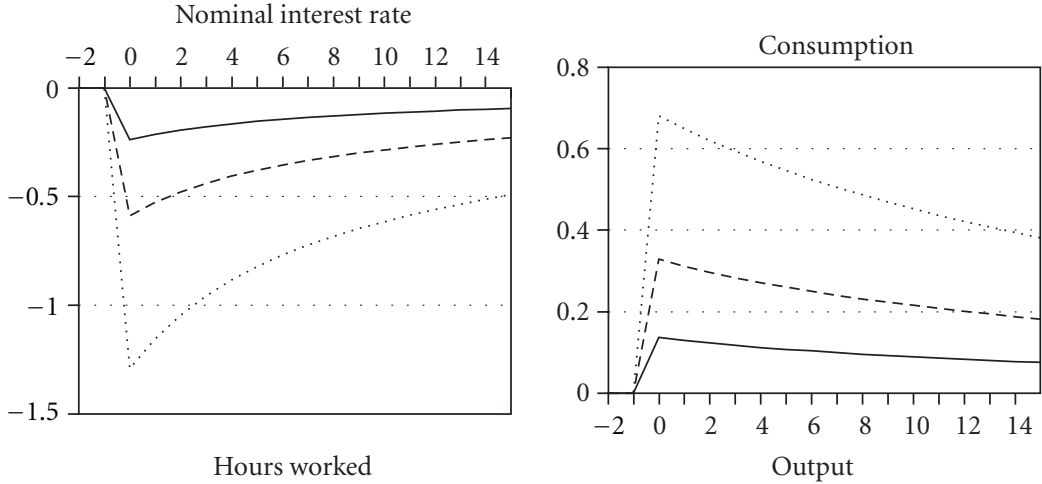

Hours worked
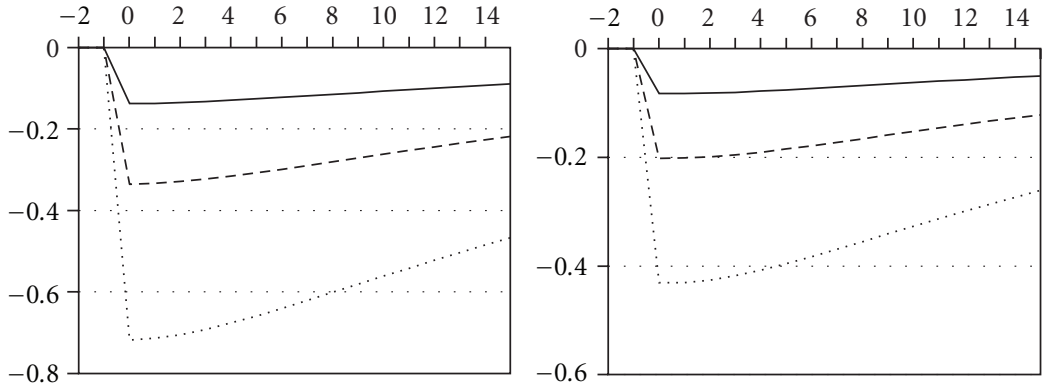

Figure 3: Dynamic response to a 1-standard deviation remittances shock. Percent deviation from steady state in vertical axis and quarters in horizontal axis. $-2 \%,-\ldots 5$, and ... $10 \%$ of GDP.

from a remittances shock under alternative assumption with respect to the motives to remit and with respect to the relative importance of such flows, in terms of GDP and in terms of the income of the representative household.

The typical remittances shock increases consumption and lowers work effort on impact, improving the utility of the representative household. It also results in a small oneperiod increase in inflation that forces the domestic currency to depreciate on impact, but since it also creates a liquidity effect, it gives way to a subsequent appreciation through the uncovered interest rate parity condition. However, the decline in the interest rate is not strong enough to increase investment, given the reduction of the marginal product of capital, such that the persistent decline in labor combined with the initially lower capital leads to a persistent drop in output.

The literature on remittances has been trying to measure the contribution of these types of inflows in the economic growth of the receiving countries, and our results provide further evidence that such inflows can have a detrimental effect on labor, and thus on economic growth. Our results indicate that the labor response plays a central role in the determination of output, but through its impact on the marginal product of capital it also affects the amount of investment, and thus capital, that the receiving country will conduct. However, since remittances also provide an inflow of financial resources to the financial system, it also generates a liquidity effect that makes borrowing more accessible. In fact, our results also indicate that when remittances are increasingly geared towards investment capital accumulation will be enhanced, such that the detrimental effect on output would be attenuated. The negative impact on output will be also reduced when remittances are a larger share of GDP or a smaller fraction of labor income. This finding reinforces current initiatives that are trying to direct more remittances towards investment.

This prolonged deterioration of GDP in response to the remittances shock is present in all of our specifications except in the case in which we allow for a more transitory shock. When the persistence parameter of the remittances shock is lowered, the decline in labor is attenuated, and its subsequent recovery accelerates. Capital accumulation is also enhanced when the remittances shock is more transitory. These two dynamics produce a smaller initial decline in output, but also generate a faster recovery of output in the following quarters, with output actually rising above steady-state levels sooner when the persistent parameter is reduced. This last finding suggests that the persistence of remittances shock is crucial for the long-term response of GDP, with longterm continuous flows of remittances giving way to more permanent increases in leisure and more transitory shocks allowing for quicker recoveries and even improvements in GDP.

\section{References}

[1] Inter-American Development Bank, Remittances to Latin America and the Caribbean in 2011, Regaining Growth, Washington, DC, USA, 2012.

[2] P. K. Narayan, S. Narayan, and S. Mishra, "Do remittances induce inflation? Fresh evidence from developing countries," Southern Economic Journal, vol. 77, no. 4, pp. 914-933, 2011. 

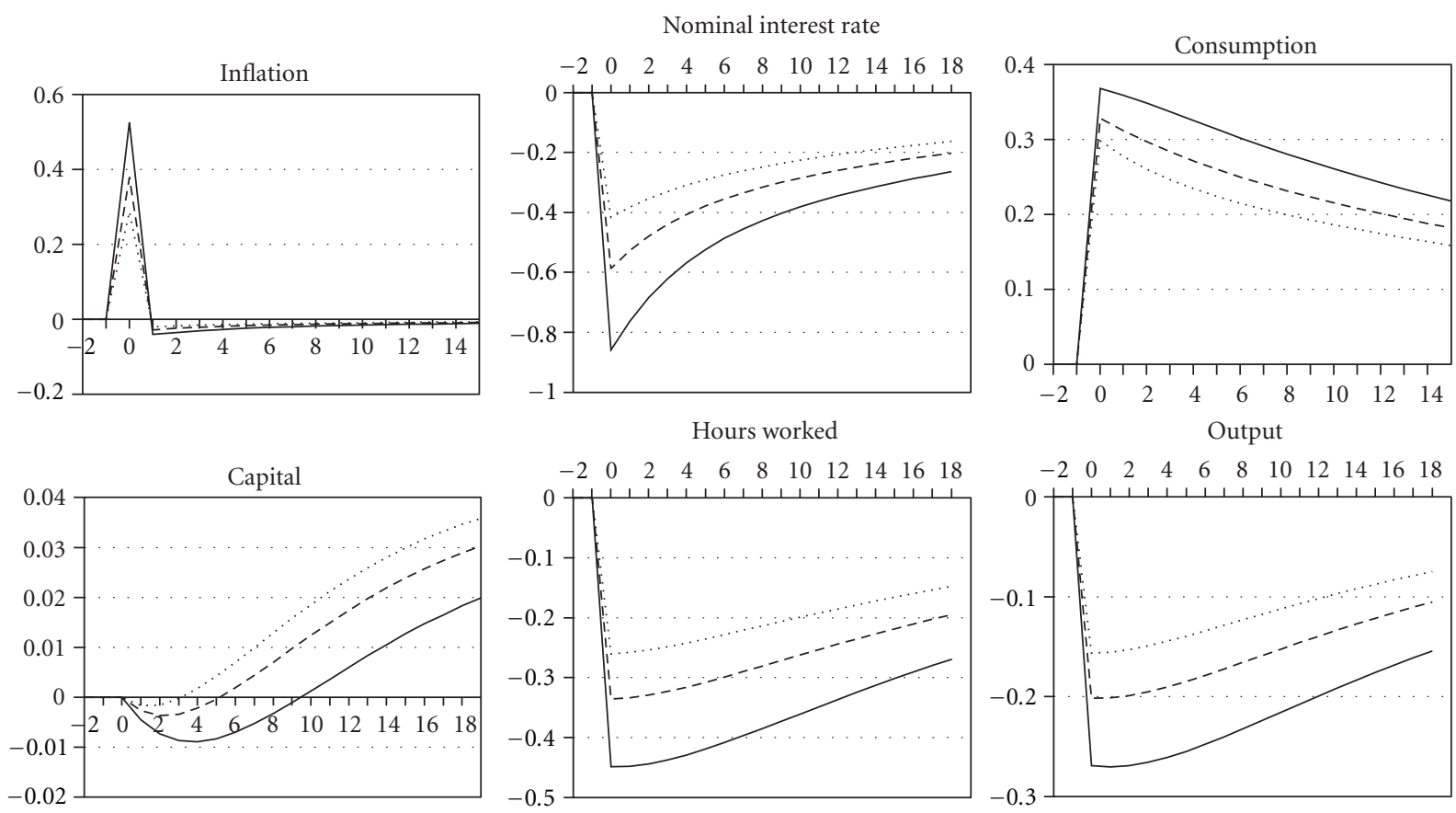

Figure 4: Dynamic response to a 1 standard deviation remittances shock. Percent deviation from steady state in vertical axis and quarters in horizontal axis. —- $20 \%,--25 \%$, and ... $30 \%$ of total time devoted to work.
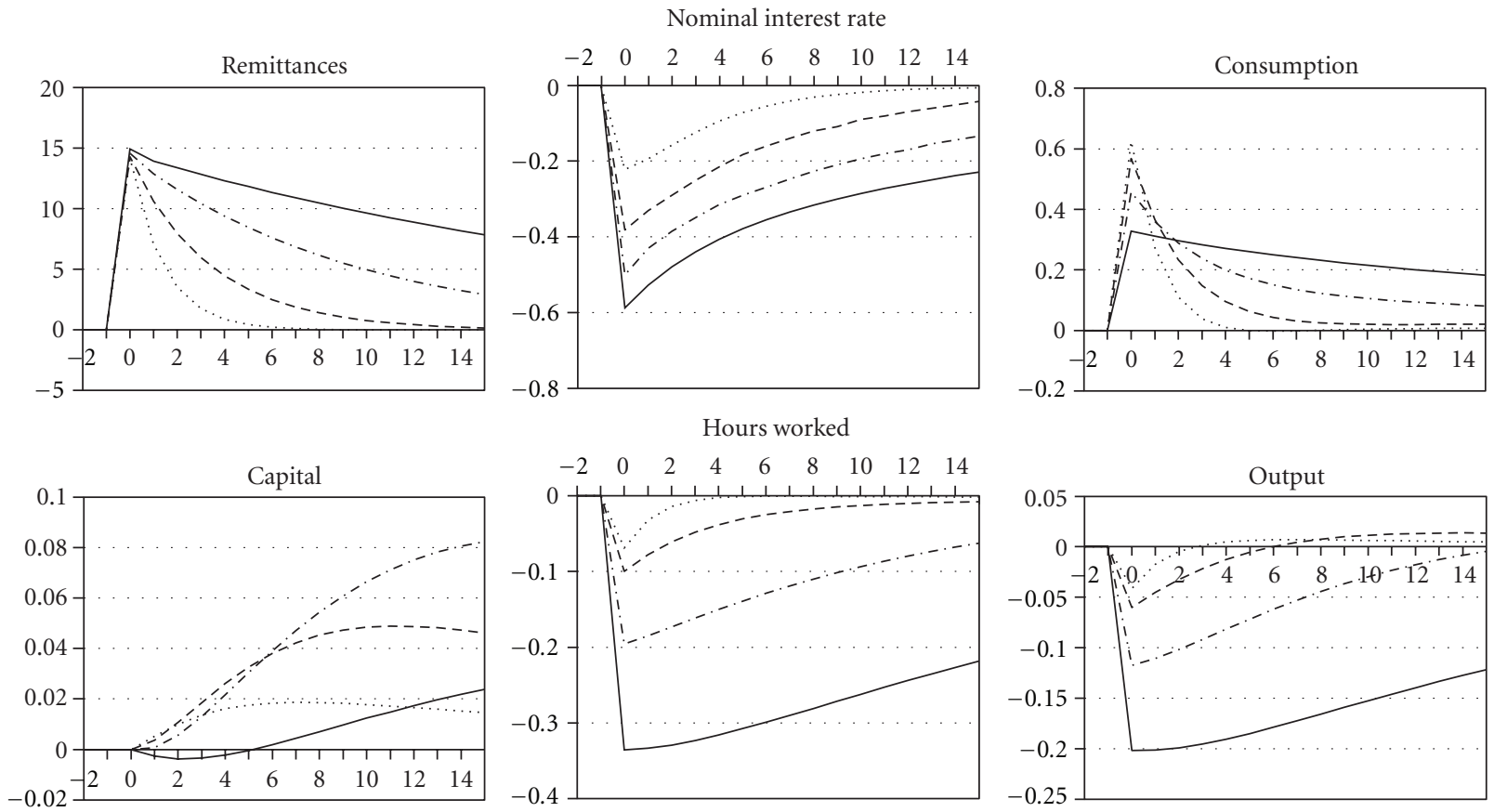

FIGURE 5: Dynamic response to a 1-standard deviation remittances shock. Percent deviation from steady state in vertical axis and quarters in horizontal axis. $-0.96,-\cdot-0.9,--0.7$, and .. 0.5 autocorrelation of remittances. 
[3] D. E. Vacaflores, "Remittances, monetary policy andpartial sterilization," Southern Economic Journal. In press.

[4] C. Amuedo-Dorantes and S. Pozo, "Workers' remittances and the real exchange rate: a paradox of gifts," World Development, vol. 32, no. 8, pp. 1407-1417, 2004.

[5] P. A. Acosta, E. K. K. Lartey, and F. S. Mandelman, "Remittances and the Dutch disease," Journal of International Economics, vol. 79, no. 1, pp. 102-116, 2009.

[6] E. Funkhouser, "Migration from Nicaragua: some recent evidence," World Development, vol. 20, no. 8, pp. 1209-1218, 1992.

[7] G. Hanson, "Emigration, remittances, and labor force participation in Mexico," Integration and Trade Journal, vol. 27, pp. 73-103, 2007.

[8] R. Chami, T. Cosimano, and M. Gapen, "Beware of Emigrants Bearing Gifts: Optimal Fiscal and Monetary Policy in the Presence of Remittances," IMF Working Paper WP/06/61, 2008.

[9] D. W. Jansen and D. E. Vacaflores, "Remittances, Migration and the Small Open Economy," Working Paper, 2011.

[10] L. R. C. áceres and N. Saca, "What Do Remittances Do? Analyzing the Private Remittance Transmission Mechanism in El Salvador," IMF Working Paper, WP/06/250, 2006.

[11] U. O. Osili, "Remittances and savings from international migration: theory and evidence using a matched sample," Journal of Development Economics, vol. 83, no. 2, pp. 446-465, 2007.

[12] F. S. Mandelman, "Monetary and exchange rate policy underremittance fluctuations," Journal of Development Economics. In press.

[13] D. E. Vacaflores, R. P. Kishan, and J. Trinidad, "Remittances, international reserves, and exchange rate regimes," Texas State University Working Paper, 2012.

[14] R. Lucas and O. Stark, "Motivations to remit: evidence from botswana," Journal of Political Economy, vol. 93, no. 5, pp. 901918, 1985.

[15] R. Chami, C. Fullenkamp, and S. Jahjah, "Are immigrant remittance flows a source of capital for development?" IMF Staff Papers, vol. 52, no. 1, pp. 55-81, 2005.

[16] J. A. Frankel, "Are Bilateral Remittances Countercyclical?" NBER Working Paper No. 15419, 2009.

[17] A. Barajas, R. Chami, C. Fullenkamp, M. Gapen, and P. Montiel, "Do Worker's Remittances Promote Economic Growth?" IMF Working Paper WP/09/153, 2009.

[18] I. C. Neagu and M. Schiff, "Remittance Stability, Cyclicality and Stabilizing Impact in Developing Countries," World Bank Policy Research Paper No. 5077, 2009.

[19] C. B. Durdu and S. Sayan, "Emerging market business cycles with remittance fluctuations," IMF Staff Papers, vol. 57, no. 2, pp. 303-325, 2010.

[20] J. Durand, W. Kandel, E. A. Parrado, and D. S. Massey, "International migration and development in Mexican communities," Demography, vol. 33, no. 2, pp. 249-264, 1996.

[21] C. Woodruff and R. Zenteno, "Migration networks and microenterprises in Mexico," Journal of Development Economics, vol. 82, no. 2, pp. 509-528, 2007.

[22] A. Cox-Edwards and M. Ureta, "International migration, remittances, and schooling: evidence from El Salvador," Journal of Development Economics, vol. 72, no. 2, pp. 429-461, 2003.

[23] A. Cox-Edwards and E. Rodríguez-Oreggia, "Remittances and labor force participation in Mexico: an analysis using propensity score matching," World Development, vol. 37, no. 5, pp. 1004-1014, 2009.

[24] E. Funkhouser, "The effect of emigration on the labor market outcomes of sender household: a longitudinal approach using data from nicaragua," Well-Being and Social Policy, vol. 2, no. 2, pp. 5-25, 2006.

[25] P. A. Samuelson, "The transfer problem and transport costs, II: analysis of effects of trade impediments," The Economic Journal, vol. 64, no. 254, pp. 264-289, 1954.

[26] J.-O. Hairault, L. Patureau, and T. Sopraseuth, "Overshooting and the exchange rate disconnect puzzle: a reappraisal," Journal of International Money and Finance, vol. 23, no. 4, pp. 615-643, 2004.

[27] F. Karamé, L. Patureau, and T. Sopraseuth, "Limited participation and exchange rate dynamics: does theory meet the data?" Journal of Economic Dynamics and Control, vol. 32, no. 4, pp. 1041-1087, 2008.

[28] R. Kollmann, "Monetary policy rules in the open economy: effects on welfare and business cycles," Journal of Monetary Economics, vol. 49, no. 5, pp. 989-1015, 2002.

[29] F. Ghironi, "Macroeconomic interdependence under incomplete markets," Journal of International Economics, vol. 70, no. 2, pp. 428-450, 2006.

[30] P. Giuliano and M. Ruiz-Arranz, "Remittances, financial development, and growth," Journal of Development Economics, vol. 90, no. 1, pp. 144-152, 2009.

[31] R. Aggarwal, A. Demirgüç-Kunt, and M. S. M. Pería, "Do remittances promote financial development?" Journal of Development Economics, vol. 96, no. 2, pp. 255-264, 2011.

[32] C. B. Keely and Bao Nga Tran, "Remittances from labor migration: evaluations, performance and implications," International Migration Review, vol. 23, no. 3, pp. 500-525, 1989.

[33] M. León-Ledesma and M. Piracha, "International migration and the role of remittances Eastern Europe," International Migration, vol. 42, no. 4, pp. 66-83, 2004.

[34] H. De Haas, "Migration, remittances and regional development in Southern Morocco," Geoforum, vol. 37, no. 4, pp. 565$580,2006$.

[35] D. Ratha, "Worker's remittances: an important and stable source of external development finance," in World Bank, Global Development Finance, pp. 157-175, 2003.

[36] World Bank, "The development impact of workers' remittances in latin America, vol. 2: detailed findings," Tech. Rep. 37026, Washington, DC, USA. 


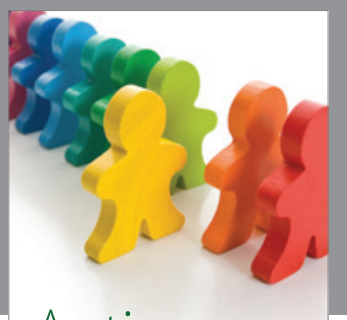

Autism

Research and Treatment
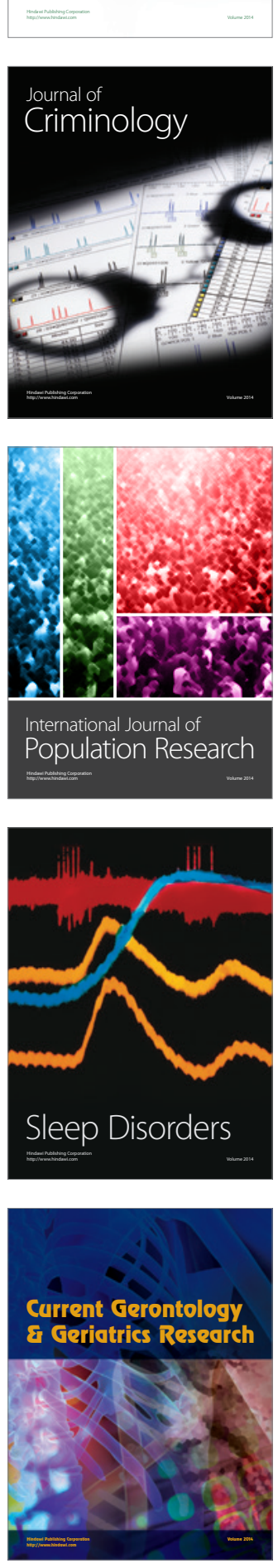
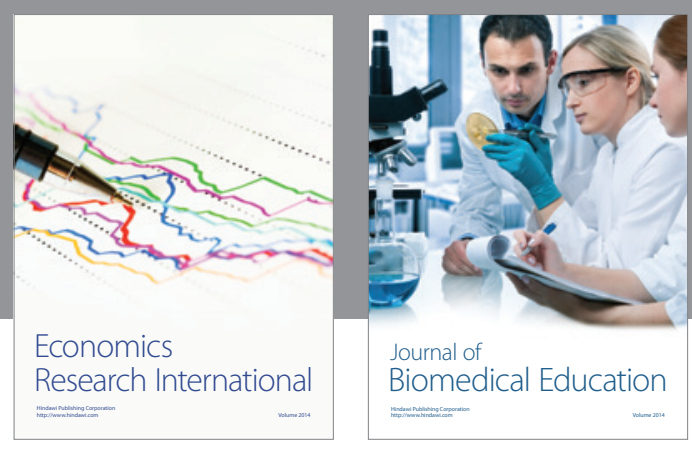

Journal of

Biomedical Education

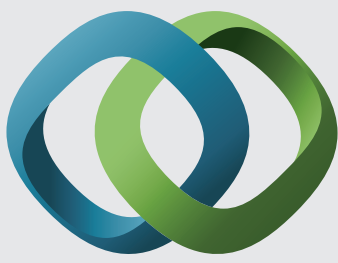

\section{Hindawi}

Submit your manuscripts at

http://www.hindawi.com
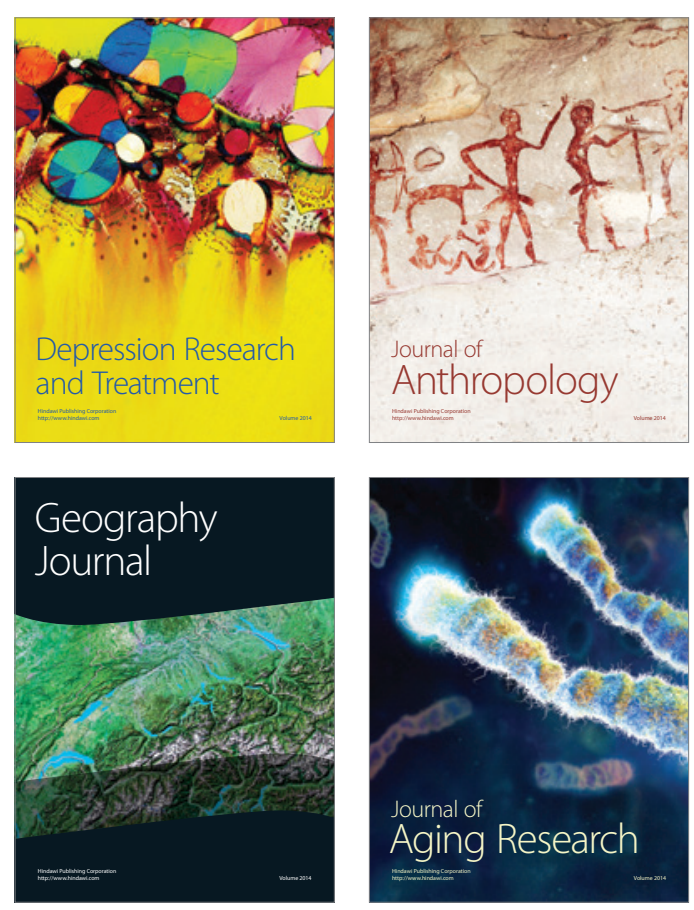

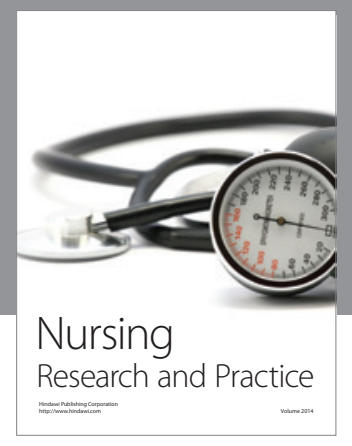

Nursing

Research and Practice

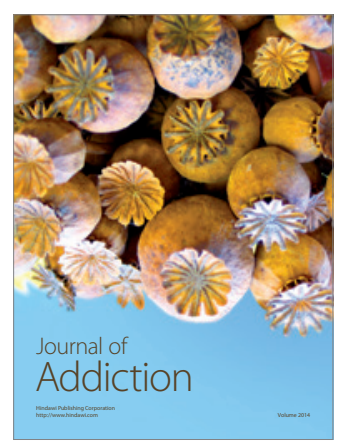

Child Development

Research

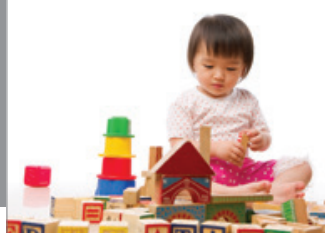

迥
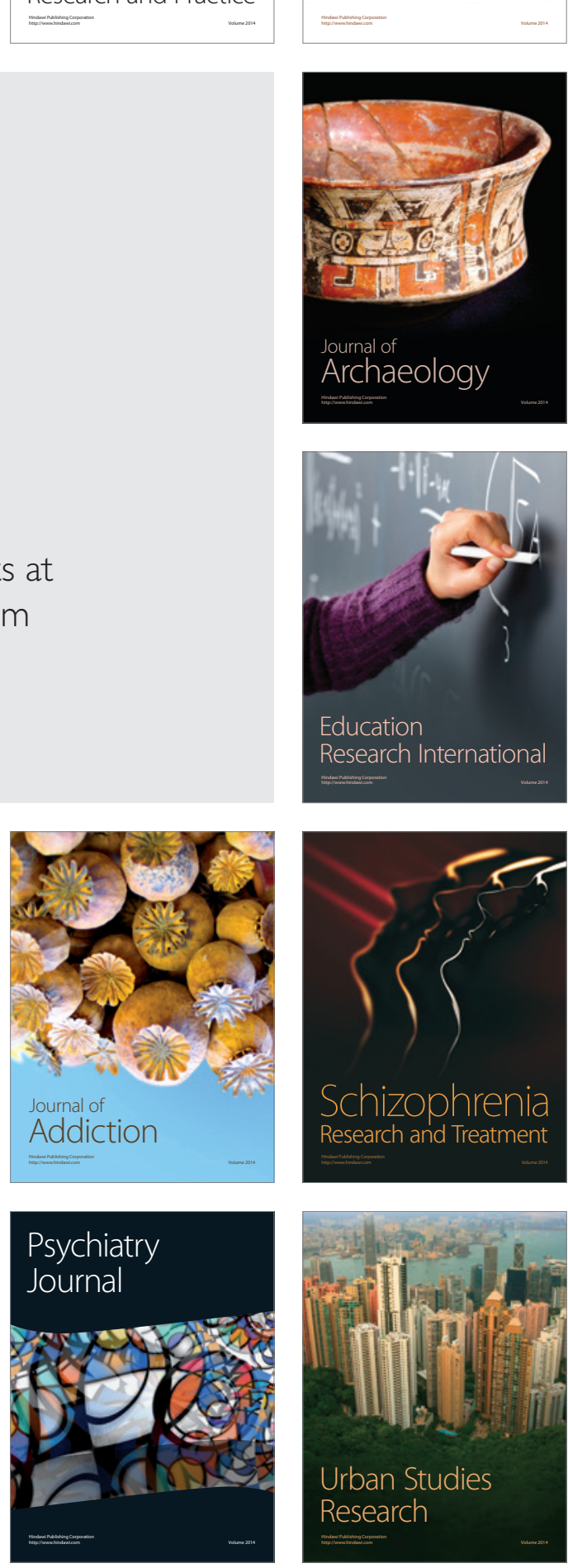